\title{
The Ocean Carbon Sink and Climate Change: A Scientific and Ethical Assessment
}

\author{
Choy Yee Keong
}

\begin{abstract}
The world's oceans which serve an important function in regulating anthropogenically driven climate change are rapidly degraded due to rising levels of atmospheric carbon emission and concentration linked to human activities. Particularly threatened are marine phytoplankton communities which constitute a significant part of the global climate control system. The main purpose of this paper is to address this critical issue by raising environmental awareness concerning the inextricable relationship between ocean carbon sink, climate change and human long-term existence based on a scientific assessment of the ecological functions of the oceans. This is expected to prompt human urgency to work towards arresting the increasing anthropogenic pressures exerted on the oceans. It also further considers the role of environmental ethics to guide, inspire and motivate individuals to act against further deterioration of our oceans. It is concluded that raising environmental awareness and promoting the ethics of sustainable resource use constitute one of the major keys in arresting further impoverishment of the health of our oceans.
\end{abstract}

Index Terms-Ocean sustainability, climate change, ocean carbon sink, biological carbon pump, anthropocentrism, ecocentrism.

\section{INTRODUCTION}

To many people, the image of our oceans is that they are "beautiful, sublime, and glorious and, mild, majestic, foaming, free", constituting an "image of eternity", to borrow the lines from a poem by Bernard Barton (1784-1849), The Sea [1]. However, behind the veil of their "image of eternity", the global oceans undertake a critical life-support function in sustaining human long-term existence. More specifically, they act as a global climate control system by regulating surface temperature and the concentration of carbon dioxide $\left(\mathrm{CO}_{2}\right)$ in the atmosphere. This in turn helps to mitigate climate change impacts. In this light, it may be noted that $\mathrm{CO}_{2}$ that remains in the atmosphere acts as a greenhouse gas, absorbing solar radiation (heat) in the atmosphere and thus causing global warming and hence, climate change. However, once it enters into the oceans by molecular diffusion (see, Fig. 1), it no longer traps heat and hence reducing the impact of global warming.

In the atmosphere carbon occurs mainly as $\mathrm{CO}_{2}$, in the terrestrial biosphere, carbon occurs mainly as organic compounds while in the sea, it mainly takes the forms of

Manuscript received August 18, 2018; revised May 13, 2019. This work is supported by MEXT*-Supported Program for the Strategic Research Foundation at Private University, 2014-2018 (*Ministry of Education, Culture Sports, Science and Technology, Japan).

Choy Yee Keong is with the Faculty of Economics, Keio University, Tokyo, Japan (e-mail: choy3293@gmail.com). bicarbonate and carbonate ions. The oceans contain about 50 times more $\mathrm{CO}_{2}$ than the atmosphere and about 19 times more than the terrestrial biosphere [2], [3]. This translates to mean that the oceans are the driver of the global carbon cycle and the largest reservoir of carbon, not the atmosphere. In addition, since 1955, the oceans, which serve as a "blue lung" of the planet, have capture over 90 percent of the excess heat trapped by greenhouse gases with 30 percent of this being stored at depths of more than 700 metres [2], [4]. This helps to stabilise the Earth's climate system.

However, today, our oceans are in peril due to rapidly rising atmospheric $\mathrm{CO}_{2}$ emissions and concentrations caused by human actions such as unrestraint fossil fuel burning, cement production and land-use changes. The extent of ecological disturbances of the oceans including their marine ecosystems is further worsened by human-induced pollutions including mercury pollution coming from the coal-fired power plants, acidification and deoxygenation [5]-[8]. The phytoplankton which play a critical role in carbon sequestration, for instance, are dying off quickly because of these environmental disruptions [9], [10].

Without taking drastic action to halt further human inflictions on our oceans, it will have adverse consequences on our long-term existence caused by the destabilization of the Earth's climate system and worsening warming impacts. Worsening warming impacts will result in some of the following adversities which threaten human survival: i) more and more intense rainfall patterns especially in the mid- to high-latitude land areas in the Northern Hemisphere, ii) declining rainfall especially in the tropics and subtropics in both the Northern and Southern hemispheres with abnormal rainfall patterns (heavy and extreme), iii) more extreme rainstorms, leading to widespread floods and soil erosion. It is noteworthy that flooding is the most prevalent disaster in North Africa, the second most common in East, South and Central Africa, and the third most common in West Africa, iv) frequent drought, which for example, has resulted in 40 to 60 percent drop of the total available water of the African large catchment basins of Niger Lake Chad and Senega and, v) heat waves or extreme heat events due to the cumulative effects of human-induced climate change. It is relevant to note that the heat waves which swept across Europe in 2003 had killed more than 80,000 people, the deadliest in world history [11].

It is contended the continued ecological deterioration of our oceans and marine ecosystems is fundamentally due to the lack of human ethical engagement with the natural world when optimizing its economic use. This is in turn attributed to the lack of environmental awareness of the role of oceans in the climate systems and the implications of man-induced ocean degradation on human survival. Against this backdrop, 
this article aims to provide a scientific assessment of the importance of oceans in regulating global warming and the biological mechanisms involved with the view of raising environmental awareness and promoting pro-environmental behaviours and actions.

The paper first examines the role plays by phytoplankton in regulating atmospheric $\mathrm{CO}_{2}$ concentrations. This is followed by a discussion on the impact of changing environmental conditions on the capacity of the phytoplankton in regulating atmospheric carbon concentrations and global warming. This line of analysis is expected to prompt deep thought concerning our relationship with the oceans and the negative consequences of unrestraint human disturbances on the ecological health of the oceans. This provides the moral impulse to guide, inspire and motivate environmental and ethical behavioral changes in our interaction with the non-human environment. It is concluded that one of the critical means to limit our impacts on the oceans is to show greater moral concern and ethical responsibility to the non-human world.

\section{OCEAN AND CLIMATE SYSTEM}

The global oceans which cover about 71 percent of the Earth's surface, about 360 million square kilometres, and with a volume of about 1,370 million cubic kilometres (329 million cubic miles), constitute a critical part of the climate system. They play a crucially important role in regulating global warming and climate change through atmosphere-ocean surface exchange of the heat trapping $\mathrm{CO}_{2}$ (Fig. 1).

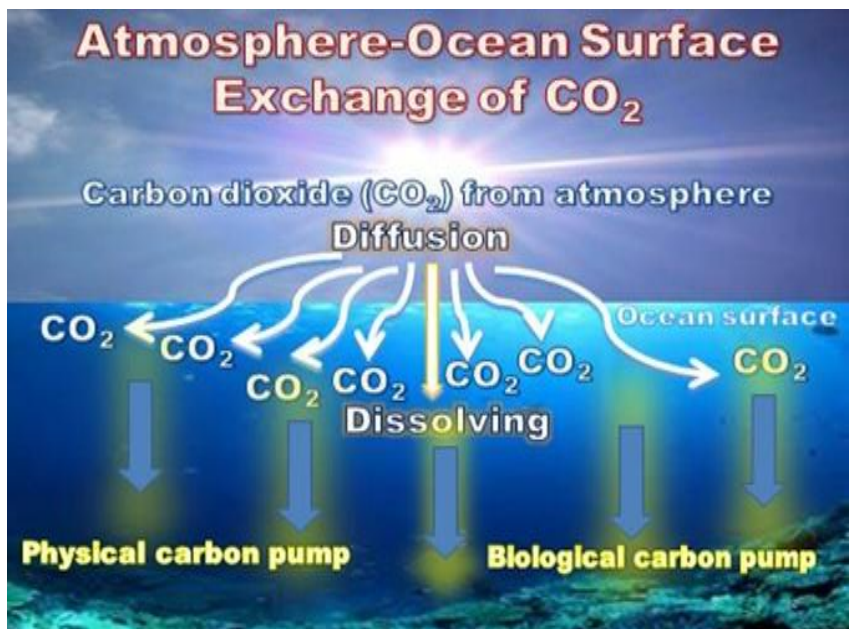

Note: $\mathrm{CO}_{2}$ moves between the atmosphere and the ocean by molecular diffusion when there is a difference in partial pressure of $\mathrm{CO}_{2}\left(\mathrm{pCO}_{2}\right)$ between the atmosphere and oceans. For example, when the atmospheric $\mathrm{pCO}_{2}$ is higher than the surface ocean, $\mathrm{CO}_{2}$ diffuses across the air-sea boundary into the sea water [12]. It is then taken up by phytoplankton as one of the basic ingredients needed for photosynthesis. This biological process constitutes the biological carbon pump which transport organic carbon to the deep ocean as explained in section III and further reflected in Fig. 2. The physical carbon pump operates through the upward and downward movement of water (upwelling and downwelling) where the dense cold waters sink from the mixed layer in the ocean surface carrying with it the $\mathrm{CO}_{2}$ absorbed from the atmosphere. This $\mathrm{CO}_{2}$-laden water may take centuries to millennia to return to the ocean surface.

Fig. 1. Ocean surface exchange of carbon dioxide $\left(\mathrm{CO}_{2}\right)$.

Over the past 200 years, the oceans have taken up 500 gigatonnes of $\mathrm{CO}_{2}\left(\mathrm{GtCO}_{2}\right)$ from the atmosphere out of 1,300
$\mathrm{GtCO}_{2}$ total anthropogenic emissions [13]. A recent estimate by the IPCC (Intergovernmental Panel on Climate Change) indicates that the total carbon emission from 1750 to 2011 was 545 gigatonnes of carbon $(\mathrm{GtC})$ ( 1 gigatonne $=1$ billion tonnes) or $2,000 \mathrm{GtCO}_{2}$. Of this, 44 percent $(240 \mathrm{GtC}$ or $880.8 \mathrm{GtCO}_{2}$ ) had accumulated in the atmosphere while 28 percent $\left(155 \mathrm{GtC}\right.$ or $\left.568.85 \mathrm{GtCO}_{2}\right)$ had been taken up in the oceans. Another 28 percent $\left(150 \mathrm{GtC}\right.$ or $\left.550.5 \mathrm{GtCO}_{2}\right)$ had accumulated in the terrestrial ecosystems [14]. Even areas hundreds of miles away from any coastline are still largely influenced by the global ocean carbon regulating system [15].

The exchange of carbon between the atmosphere and the oceans, technically known as abiotic inorganic cycling of carbon, takes place in a number of ways. Two of the most important mechanisms are through biological carbon pump and physical carbon pump (Fig. 1). The article will focus on discussing the functions of biological carbon pump which contributes to the bulk of the total carbon transported (about 80 percent) from the ocean surface to the oceanic interior. It may be noted in passing that the physical carbon pump accounts for about 20 percent of the total carbon export. The biological carbon export, technically termed as the vertical gradient in dissolved inorganic carbon is fuelled by a network of marine phytoplankton or "photoautotrophs" (photosynthesizing organisms) [16]-[18]. This is discussed in the following section.

\section{BIOLOGICAL CARBON PUMP}

Phytoplankton, spend at least a part of their life cycle suspended in water and primarily consist of diatoms, silicoflagellates, coccolithophorids, dinoflagellates, bacteria and viruses. Diatoms are considered as important in carbon flux because of their large size and fast sinking rate. Phytoplankton require light energy to perform photosynthesis and hence they can only thrive well in the sunlit euphotic zone, also known as epipelagic, photic or sunlit zone. This zone covers the surface waters up to 200 metres down the ocean where light is adequate for photosynthesis. During photosynthesis, phytoplankton use the dominant abiotic components, namely, sunlight, $\mathrm{CO}_{2}$ and water to convert into proteins, fats, and carbohydrates, which they use for food, and to make their cells. $\mathrm{CO}_{2}$ is an extensive source of inorganic carbon found in the atmosphere where the concentration in July 2018 was roughly 408.71 parts per million (ppm).

When $\mathrm{CO}_{2}$ dissolves in seawater, it can exist in various dissolved forms including aqueous carbon dioxide, $\left(\mathrm{H}_{2} \mathrm{CO}_{3}\right)$ (one percent), bicarbonate $\left(\mathrm{HCO}_{3}^{-}\right)(\sim 90$ percent), carbonate $\left(\mathrm{CO}_{3}{ }^{2-}\right)$ ( $~ 9$ percent $)$, and the minor form, carbonic acid which constitutes less than 0.3 percent of aqueous $\mathrm{CO}_{2}$ concentration [19]-[21]. Bicarbonate is a form of carbon that does not escape the ocean easily. The sum of the concentrations of all these dissolved forms of $\mathrm{CO}_{2}$ is the inorganic carbon concentration and is signified as $\sum \mathrm{CO}_{2}$ [22]. Once dissolved, inorganic carbon is converted to organic matter through photosynthesis. This is known as primary production, that is, the synthesis of organic compounds from atmospheric $\mathrm{CO}_{2}$. In the process, oxygen is also released as a waste product [23]. This is further elaborated in the last part 
of this section.

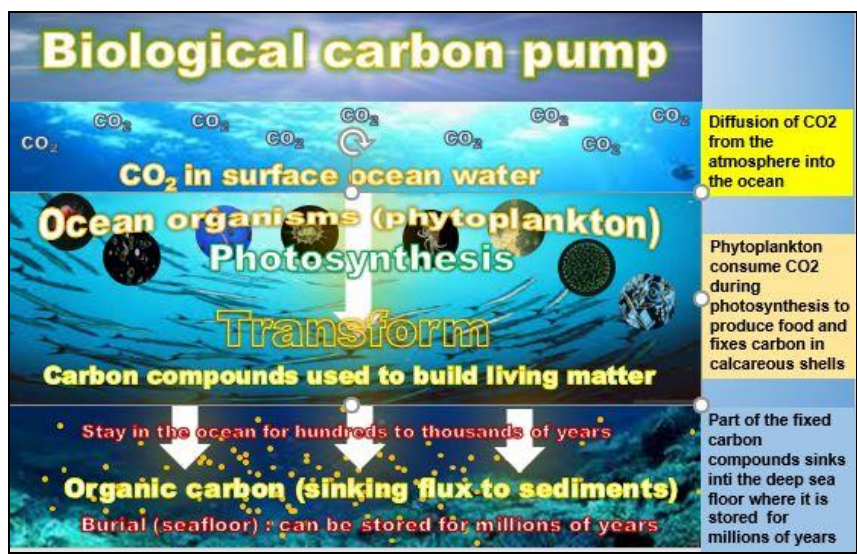

Note: the diagram shows how atmospheric carbon is converted into organic carbon which eventually find its way to the deep sea-bed for very long periods of time

Fig. 2. Biological carbon pump mechanism.

Oceanic primary carbon production by phytoplankton represents about half of the planet's primary production, ranging from 35 to $65 \mathrm{GtC}$ per year [24]. Some of these organic carbon matters are subsequently transferred to the deep ocean through gravitational sinking known as carbon export as noted above. It is estimated that about 20 percent of the carbon export is transferred to the deep ocean in the mid-water zone (twilight zone or Mesopelagic Zone extending from 200 to 1000 metres deep), providing an important source of carbon for the microbial communities thrive in this zone [25]. In turn, only a tiny fraction of this export production survives respiration and is exported below the thermocline to the cooler deep water in the bathypelagic or aphotic zone. A thermocline is the transition layer between warmer mixed water at the ocean's surface in the euphotic zone and cooler deep water in the mesopelagic zone. Mesopelagic zone is the mid-water zone which does not carry enough light for photosynthesis to take place.

It is generally claimed that 0.1 to 1 percent of the carbon-export finally reaches the seabed in mesopelagic zone where it can turn into fossil fuel deposits [15], [26]. As sunlight does not penetrate to this eternally dark mesopelagic zone, carbon is sequestered out of further contact with the atmosphere on time scales of months to millennia [25], [27], [28]. In this way, the biological carbon pump serves as a global climate control system by storing the heat-trapping $\mathrm{CO}_{2}$ in the form of organic carbon in the deep-sea bed for a long period of time.

In addition, the phytoplankton also produce much of the oxygen we breath. It is noteworthy that while the tropical rainforests contribute to roughly 28 percent of oxygen turnover (often mistaken as production), processing it through photosynthesis, the photosynthetically active phytoplankton and bacteria generate most of the oxygen in the atmosphere. It is estimated that these planktonic organisms generate between 50 to 70 percent of oxygen through photosynthesis-the largest source of the planet's oxygen. This is incredible given the fact that the total living biomass in the marine environment is only about one to two-hundredths of the forests and grasslands on land [29], [30]. This means that primary producers in the ocean are around two hundred times more productive than land living biomass with respect to their mass [29].

\section{PhytoplankTON IN PERIL}

It is thus increasingly clear in light of the above that the biological carbon pump constitutes a key mechanism in the global climate system for sequestering carbon on a global scale and for very long periods of time, hence helping to mitigate anthropogenic climate change. Viewed from this perspective, it may safely be claimed that the biologically driven carbon cycle in the ocean constitutes one the most important ecosystem services underpinning human long-term existence. However, the planktonic marine ecosystem is very susceptible to traumatic changes of the ocean environmental conditions. For example, the phytoplankton organisms which have short life cycles ranging from hours to days respond rapidly to environmental changes such as changes of $\mathrm{pH}$ value (acidity) or temperature of the ocean. The term, $\mathrm{pH}$ (power of hydrogen) is a negative log of hydrogen ion concentration used to specify the acidity or basicity (alkalinity) of an aqueous (water-based) solution.

A pH of 7.0 is neutral; above 7.0 is basic and below 7.0 is acidic; close to 7.0 is weak and far from 7.0 is strong [31]. The $\mathrm{pH}$ of seawater typically ranges between 7.5 and 8.4 [32]. Thus, changes of $\mathrm{pH}$ below its typical range renders the ocean water more acidic, a phenomenon commonly known as ocean acidification characterized by high concentrations of carbon. In digression, the $\mathrm{pH}$ scale is logarithmic and goes from 0 to 14. The lower the number, the more acidic the water is. The higher the number, the more basic (alkaline) or less acidic it is. For each whole number increase, the hydrogen ion concentration decreases tenfold, that is, each number is 10 times more basic (alkaline) than the previous number and the water becomes less acidic [32]. For example, $\mathrm{pH} 4$ is ten times more acidic than pH 5 and 100 times $(10 \times 10)$ more acidic than $\mathrm{pH} 6$ [33]. The current rate of acidification is 10 times faster than any time in the last 55 million years [34].

It must be noted that the term "acidification" refers to a slight lowering of the $\mathrm{pH}$ of ocean water, pushing it closer to the acidic end of the scale [35]. In other words, the ocean itself is not actually acidic, that is, still slightly alkaline even it has a $\mathrm{pH}$ of less than 7 . However, changes in $\mathrm{pH}$ value towards the acidic end of the scale could have dramatic impact on the marine ecosystem [33], [36]. Briefly noted, the alkalinity of seawater refers to its quantitative capacity to buffer or neutralize acidic condition. It is a measurement of the ability of the seawater to resist changes in $\mathrm{pH}$ [36].

When anthropogenic $\mathrm{CO}_{2}$ dissolves in the ocean, it forms carbonic acid which reduces the $\mathrm{pH}$ value of seawater, that is, become more acidic. Over the past 300 million years, ocean $\mathrm{pH}$ has been slightly basic, averaging about 8.2 [32], [37]. However, since the industrial revolution, it has dropped to 8.1 (weakly alkaline) and is expected to fall by another 0.3 to $0.4 \mathrm{pH}$ units by the end of the century [33]. The drop of 0.1 $\mathrm{pH}$ unit represents a 25-percent increase in acidity over the past two centuries [37].

Ocean acidification has a devastating impact on phytoplankton organisms. It makes it harder for them to absorb nutrients, rendering them vulnerable to disease, 
weakening their photosynthetic ability and turning them toxic [33], [38], [39]. Furthermore, when the seawater becomes more acidic it binds up carbonate ions and makes them less abundant-ions that phytoplankton need to build calcium carbonate shells to protect themselves from microscopic predators called ciliate protozoa [33], [35]. A disruption of the ability of phytoplankton to build their shells could have adverse impact on the ecological integrity of the planktonic ecosystem, and hence its capacity in carbon sequestration.

Ocean acidification along with climate change could lead to poor growth rates of phytoplankton organisms, thus weakening the phytoplankton assemblages [39]. This in turn would negatively affect the level of oxygen produced by the photosynthetic organisms. All in all, plankton growth rate, abundance, and species distribution are all influenced by warming and climate change [40]-[42]. This has the impact of affecting ecosystem services, such as oxygen production, carbon sequestration, and biogeochemical cycling-exerting destructive impacts on human long-term existence [42].

Ocean acidification also alters the chemical and biochemical properties of seawater such as chemical reactions, equilibrium conditions, and biological toxicity [43]. For example, a decrease in $\mathrm{pH}$ below 6.0 may increase the amount of mercury soluble in water, one of the most toxic pollutants which can further be bioaccumulated and converted to even more toxic forms such as methylmercury. An increase in $\mathrm{pH}$ above 8.5 enhances the conversion of a less toxic form of ionized ammonia $(\mathrm{NH} 4+)$ to a more toxic form of un-ionized ammonia (NH3) which is harmful to aquatic life [31], [32]. In general, the toxicity of ammonia increases as $\mathrm{pH}$ increases [44].

\section{HUMAN IMPACTS ON THE OCEANS}

It appears that many of us do not realize that the rising and excessive levels of heat-trapping $\mathrm{CO}_{2}$ released into the atmosphere do not stay in the air. Instead, they undergo a complex abiotic surface-ocean interaction and dissolves into the seawater which may result in ocean acidification as briefly discussed above. Increased levels of atmospheric $\mathrm{CO}_{2}$ will increase the level of absorption by the ocean. If the ocean is under-saturated with $\mathrm{CO}_{2}$ compared to the atmosphere, it will continue to absorb the excess heat-trapping gas. However, its absorption capacity will diminish when it reaches its saturation point. If both the oceans and the biosphere cannot absorb as much $\mathrm{CO}_{2}$, the global warming impact is expected to worsen. This will pose a severe threat to human long-term existence.

Furthermore, $\mathrm{CO}_{2}$ solubility is higher in cold water than warm water. Hence, the expansion of sea-surface temperature caused by global warming will constrain the ocean's role as a carbon sink to reduce $\mathrm{CO}_{2}$ from the atmosphere. Consequently, more $\mathrm{CO}_{2}$ will be left in the atmosphere, contributing to additional warming [45], [46]. In addition, increasing ocean surface temperatures also tend to lead to the alteration of the stable surface water stratification, changing light and nutrient availability to the detriment of the phytoplankton organisms as well as carbon export production [47]-[50]. Besides, $\mathrm{CO}_{2}$ fertilization which increases the acidity of the seawater is also the detriment of the ecological health of the phytoplanktonic ecosystem [51]. This will weaken its carbon sequestration and oxygen production capacities. If the absorptive capacities for excess $\mathrm{CO}_{2}$ for both the ocean and the biosphere have reached their maximum limits, the warming effect on the global climate will be devastating [45].

\section{ANTHROPOCENTRISM AND OCEAN SUSTAINABILITY: THE CONNECTION}

The human-induced ocean predicament is attributed to not only the lack of a clear understanding of the inextricable link between ocean sustainability and human long-term existence but also, more importantly due to the lack of ethical engagement with the environmental problems confronting us today. By and large, in the current neo-liberal economic system characterized by the fervent quest for economic growth and material progress, humans tend to hold an anthropocentric view of nature.

To emphasise, in philosophy, anthropocentrism is the belief that humans are the most important beings in the Universe and the masters of nature who subdue it for their own economic consumption [52]. It also considers that the non-human natural entities have no moral significance of their own. Furthermore, anthropocentrism treats non-human forms of life in nature only instrumentally as a means to an end, that is, as having instrumental values. It thus follows that the oceans which are central to human welfare, exist for the sake of humanity to absorb and store excess carbon and hence, they owe no direct moral duties to protect their ecological integrity.

Anthropocentrism is closely associated with egoistic value orientation. Individuals with strong egoistic value orientation tend to prioritize self-interest over collective interest. In other words, they are more concern about personal wellbeing maximization and less concern about environmental protection [53]-[55]. Environmental actions under this self-centred belief system is mainly based on self-interest justification or economic motivation. Thus, humans continue to burn fossil fuels without restraint with the self-interested aim to maximize shorten economic progress over long-term environmental benefits.

In contrast to anthropocentrism is the concept of ecocentrism. Ecocentrism or the Earth-centred belief system holds that the natural world including the oceans are the central objects for ethical concern and protection [56]-[60]. More specifically, ecocentrists value nature including its biotic and abiotic entities beyond its strict instrumental use. Put differently, it is a worldview that recognizes the intrinsic worth of nature and that its ecological integrity matters morally. Thus, ecocentrists display a strong tendency to undertake ethical obligations to bring human activity within the biophysical limit of growth and into greater harmony with nature.

Ecocentrism is associated with biospheric value orientation. Individuals with strong biospheric value orientations are concerned for the environment for its own sake, that is, for its intrinsic value without a clear and distinct link to the welfare 
of other human beings [61]. This environmental belief system constitutes an important ethical impulse for promoting pro-environmental behvaiours and sustainable resource use practices and environmental protection.

In light of the above, given that the current increased ocean acidification is largely due to human activities as discussed above [62] promoting a biospheric-value oriented society can help to shape individuals' environmental preferences and priorities to take the necessary steps or actions, some of which are listed below, to curtail both carbon footprint and ocean acidification:

1) Sustainable production and consumption practices

2) Sustainable energy use and conservation

3) Greater investment in or diversification of renewable energy sources such as solar energy or wind power with viable zero-carbon emissions.

4) Conversion of coal-fired power plants to natural gas which is less carbon intensive as it causes about 60 percent fewer carbon emissions compared to coal.

5) Intensify ocean management plans and law enforcement.

In addition to the above, it is also necessary to raise environmental awareness about the human impacts on the oceans and the risks posed by ocean acidification and climate change on human long-term existence through the promotion of environmental education. Such strategic move can instill some self-restraint disciplines and attitudes among individuals concerning environmental use and protection. Policy makers must extend more resources to invest in environmental education to provide information on these critical environmental issues and get every individual to a part of the solution. To compliment the above moves, it is also important to enact and effectively enforce laws or implement policies to ensure sustainable use of natural resources especially with regard to the burning of fossil fuels.

\section{CONCLUSIONS}

The oceans which constitute a critical part of the climate system play an important role in regulating $\mathrm{CO}_{2}$ concentrations and global warming. However, the biocapacity of the oceans to deliver this life-support service to sustain long-term human existence is under threat due to uncontrol human activities. It is contended that one of the effective ways to prevent further deterioration of the health of our oceans is for us to dismantle our unrestrained capitalist mode of resource exploitation and to build a common future in harmony with the environment via a moral and ethical engagement with nature. It may well be that thinking morally or ethically about the natural environment including the oceans can influence human beings' attitudes and aid environmental conservation. Such distinct ethical beliefs serve as a moral impulse for individuals to refrain from exerting undue influence on nature including the oceans to the detriment of long-term human existence.

\section{CONFLICT OF INTEREST}

The author declares no conflict of interest.

\section{AUTHOR CONTRIBUTIONS}

The manuscript represents valid work written solely by the author, and neither this manuscript nor one with substantially similar content under my authorship has been published or is being considered for publication elsewhere.

\section{REFERENCES}

[1] B. Barton, "The sea," The World's Best Poetry: Nature, vol. 5, Philadelphia: John D. Morris \& Co., 1904.

[2] Ocean and Climate, "Ocean and climate scientific notes," Ocean and Climate, Tome 2, October 2016.

[3] J. Goudriaan, "Atmospheric $\mathrm{CO}_{2}$, global carbon fluxes and the biosphere," in R. Rabbinge, J. Goudriaan, H. van. Keulen, F.W.T. Penning de Vries, H. H. van Laar, Eds. Theoretical Production Ecology: Reflections and Prospects, Wageningen: Pudoc, pp. 17-40, 1990.

[4] T. Wallace, "Oceans are absorbing almost all of the globe's excess heat," New York Times, September 2016.

[5] C. Bowes, "Mercury pollution from coal-fired power plants," National Wildlife Federation, National Advocacy Center, Washington D.C. March 2011.

[6] A. Besant, "Mercury levels in Pacific Ocean fish on the rise due to India, China coal plants," Public Radio International (PRI), August 2013.

[7] C. H. Lamborg et al., "A global ocean inventory of anthropogenic mercury based on water column measurements," Nature, August 2014, vol. 512, pp.65-69.

[8] C. S. Rousseaux and W. W. Gregg, "Recent decadal trends in global phytoplankton composition. Global biogeochemical cycles," Global Biogeochemical Cycles, vol. 29, pp. 1674-1688, September 2015.

[9] D. G. Boyce, M. R. Lewis, and B. Worm, "Global phytoplankton decline over the past century," Nature, vol. 466, pp. 591-596, July 2010 .

[10] M. Slezak, "Ocean's hidden green plankton revealed by fixing glitch in model," New Scientist, October 2015.

[11] Y. K. Choy, "Ecosystem health, human existence, and bio-capacity deficit: the ethical relationship," International Journal of Sustainable Development and Planning, vol. 11, no.6, pp. 1004-1016, 2016.

[12] C. L. Sabine et al., "Current status and past trends of the global carbon cycle," in C. B. Field and M. R. Raupach, Eds. The Global Carbon Cycle: Integrating Humans, Climate, and the Natural World, Washington, Covelo, London: Island Press, pp. 17-44, 2004.

[13] IPCC, IPCC Special Report on Carbon Dioxide Capture and Storage, Cambridge, United Kingdom and New York: Cambridge University Press, 2005

[14] IPCC, Climate Change 2013: The Physical Science Basis. Contribution of Working Group I to the Fifth Assessment Report of the Intergovernmental Panel on Climate Change (IPCC), Cambridge, United Kingdom and New York, NY, USA: Cambridge University Press, 2013.

[15] NOAA, Learning Ocean Science through Ocean Exploration, $3^{\text {rd }}$ ed., Washington, DC: National Oceanic and Atmospheric Administration (NOAA), 2006.

[16] R. A. Feely, C. L. Sabine, T. Takahashi, and R. Wanninkhof, "Uptake and storage of carbon dioxide in the ocean: The global $\mathrm{CO}_{2}$ survey," Oceanography, vol. 14, no. 4, pp.18-32, October 2001.

[17] CBD Secretariat, Scientific Synthesis of the Impacts of Ocean Acidification on Marine Biodiversity, Convention on Biological Diversity (CBD), Montreal, Quebec, Canada, 2009.

[18] J. Kämpf and P. Chapman, Upwelling Systems of the World: A Scientific Journey to the Most Productive Marine Ecosystems, Switzerland: Springer, 2016

[19] A. Dickson, "The carbon dioxide system in seawater: Equilibrium chemistry and measurements," in U. Riebesell, V. J. Fabry, L. Hansson and J.-P. Gattuso, Eds. Guide to Best Practices for Ocean Acidification Research and Data Reporting, Luxembourg: Publications Office of the European Union, pp. 17-40, 2010.

[20] A. S. Gupta and B. McNeil, "Variability and change in the ocean," in A. Henderson-Sellers and K. McGuffie, Eds. The Future of the World's Climate, Amsterdam, USA, UK: Elsevier, pp. 141-165.

[21] R. E. Zeebe, "History of seawater carbonate chemistry, atmospheric $\mathrm{CO}_{2}$, and ocean acidification," Annual Review of Earth Planetary Sciences, vol. 40, pp. 141-16, 2012.

[22] W. K. Dodds and M. R. Whiles, Freshwater Ecology. Concepts and Environmental Applications of Limnology, UK: Elsevier Ltd, 2010.

[23] N. Barnard and J. Grekin, "Ocean fertilization," United Nations Environment Programme and the Secretariat of the Convention on 
Biological Diversity, Biodiversity and Climate Change Issue Paper No. 8, 2009.

[24] P. A. Giorgio and C. M. Duarte, "Respiration in the open ocean," Nature, vol. 420, no. 6914, pp. 379-84, November 2002.

[25] Siegel et al. "Prediction of the export and fate of global ocean net primary production: The EXPORTS science plan," Frontiers in Marine Science, vol. 3, no. 22, pp. 1-22, March 2016.

[26] D. M. Sigman and M. P. Hain, "The biological productivity of the ocean," Nature Education, vol. 3, no. 6, pp. 1-16, 2012.

[27] S. Honjo et al., "Understanding the role of the biological pump in the global carbon cycle: An imperative for ocean science," Oceanography, vol. 27, no. 3, pp. 10-16, October 2014.

[28] L. Guidi et al., "Plankton networks driving carbon export in the oligotrophic ocean," Nature, vol. 532, pp. 465-470, April 2016.

[29] World Ocean Review, World Ocean Review 1. Living with the Ocean, Hamburg: maribus $\mathrm{gGmbH}$ in cooperation with The Future Ocean, Germany and The International Ocean Institute, Malta, 2010.

[30] J. L. Sarmiento and M. Bender, "Carbon biogeochemistry and climate change," Photosynthesis Research, vol. 39, pp. 209-234, 1994.

[31] W. A. Wurts, "Daily $\mathrm{pH}$ cycle and ammonia toxicity," World Aquaculture, vol. 34, no. 2, pp. 20-21, 2003.

[32] CWT (Clean Water Team), "pH fact sheet, S-3.1.4.0(pH)," The Clean Water Team Guidance Compendium for Watershed Monitoring and Assessment, Version 2.0., Division of Water Quality, California State Water Resources Control Board (SWRCB), Sacramento, C, pp. 1-5, 2004.

[33] Smithsonian. Ocean Acidification, "The ocean portal team," Smithsonian, Washington D.C., April 2018.

[34] C. Salisbury, "Ocean acidifying 10 times faster than anytime in the last 55 million years, putting polar ecosystems at risk," Mongabay.com, U.S.A. February 2014.

[35] T. Stephen, "Ocean acidification could have broad effects on marine ecosystems," Newscenter, UC Santa Cruz, Regent of the University of California, December 2008.

[36] Fondriest Environmental, Inc., "pH of water," Fundamentals of Environmental Measurements, November, 2013.

[37] National Geographic, Ocean Acidification. National Geographic, April 2017.

[38] M. Baskin, "Acid seas threaten creatures that supply half the world's oxygen," Crosscut, Seattle, WA, June 2014.

[39] A. D. McKinnon, A. J. Richardson, M. A. Burford, and M. J. Furnas, "Vulnerability of great barrier reef plankton to climate change," Climate Change and the Great Barrier Reef: A Vulnerability Assessment, Great Barrier Reef Marine Park Authority, Australia, Department of the Environment and Heritage, Australian Government Office, Australia, pp. 121-152, 2007

[40] G. Beaugrand, P. C. Reid, F. Ibanez, J. A. Lindley, and M. Edwards, "Reorganization of North Atlantic marine copepod biodiversity and climate," Science, vol. 296, pp. 1692-1694, May 2002.

[41] M. Edwards and A. J. Richardson, "Impact of climate change on marine pelagic phenology and trophic mismatch," Nature, vol. 430, pp 881-884, June 2004.

[42] A. J. Richardson and D. S. Schoeman, "Climate impact on plankton ecosystems in the Northeast Atlantic," Science, vol. 305, no. 5690, pp.1609-1612, September 2004.

[43] G. M. Marion, F. J. Millero, M. F. Camões, P. Spitzer, R. Feistel, and T. A. Chen, "pH of seawater," Marine Chemistry, vol. 126, pp. 89-96, 2011.

[44] S. M. Levit, A Literature Review of Effects of Ammonia on Fish, Bozeman, Montana: Center for Science in Public Participation, 2010.

[45] H. Riebeek, "The ocean's carbon balance," NASA Earth Observatory, USA, July 2008.

[46] C. Nellemann, E. Corcoran, C. M. Duarte, L. Valdés, C. Young, L. Fonseca, and G. Grimsditch, Blue Carbon. A Rapid Response
Assessment, United Nations Environment Programme, GRID-Arendal, 2009.

[47] J. Taucher and A. Oschlies, "Can we predict the direction of marine primary production change under global warming?" Geophysical Research Letter, vol. 38, LO2603, pp. 1-6, January 2011.

[48] L. Bopp et al., "Multiple stressors of ocean ecosystems in the 21st century: Projections with CMIP5 models," Biogeosciences, vol. 10, no. 10, pp. 6225-6245, October 2013.

[49] S. Dutkiewicz, J. R. Scott, and M. J. Follows, "Winners and losers: Ecological and biogeochemical changes in a warming ocean," Global Biogeochemical Cycles, vol. 27, pp. 463-477, April 2013.

[50] P. W. Boyd, "Framing biological responses to a changing ocean," Nature and Climate Change, vol. 3, pp. 530-533, May 2013.

[51] U. Sommer, C. Paul, and M. Moustaka-Gouni, "Warming and ocean acidification effects on phytoplankton - From species shifts to size shifts within species in a mesocosm experiment," PLOS ONE, vol. 10, no. 5, pp. 1-17, May 2015.

[52] H. Rolston, "Environmental ethics," The Blackwell Companion to Philosophy, Oxford: Blackwell Publishing, pp. 517-530.

[53] P. C. Stern, T. Dietz, and A. Guagnano, "A brief inventory of values," Educational and Psychological Measurement, vol. 58, no. 6, pp. 984-1001

[54] A. M. Nordlund and J. Garvill, "Value structures behind proenvironmental behavior," Environment and Behavior, vol. 34, no. 6, pp. 740-756, 2002.

[55] T. Dietz, A. Fitzgerald, and R. Shwom, "Environmental values," Annual Review of Environment and Resources, vol. 30, pp. 335-372, 2005.

[56] A. Leopold, A Sand County Almanac, New York: Oxford University Press, 1949.

[57] J. B. Callicott, In Defense of Land Ethic: Essays in Environmental Philosophy, Albany: State University of New York Press, 1989.

[58] J. B. Callicott, Beyond the Land Ethic. More Essays in Environmental Philosophy, Albany: State University of New York Press, 1999.

[59] Y. K. Choy, "Land ethic from the borneo tropical rainforests in Sarawak, Malaysia: An empirical and conceptual analysis," Environmental Ethics, vol. 36, no. 4, pp. 421-441, 2014.

[60] Y. K. Choy, "Cost-benefit analysis, values, wellbeing and ethics: An indigenous worldview analysis," Ecological Economics, vol. 145, pp. $1-9,2018$.

[61] L. Steg, G. Perlaviciute, E. Werff, and J. Lurvink, "The significance of hedonic values for environmentally relevant attitudes, preferences and actions," Environment and Behavior, vol. 46, no. 2, pp. 163-192, 2014.

[62] MIT, "Increased ocean acidification is due to human activities, say scientists: More anthropogenic carbon in the northeast Pacific means weaker shells for many marine species," Massachusetts Institute of Technology (MIT), Cambridge, MA, ScienceDaily, September 2016.

Copyright $\odot 2019$ by the authors. This is an open access article distributed under the Creative Commons Attribution License which permits unrestricted use, distribution, and reproduction in any medium, provided the original work is properly cited (CC BY 4.0).

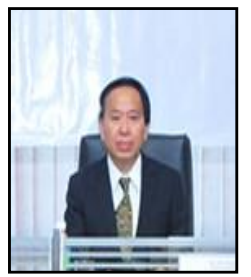

Choy Yee Keong is a graduate of the Institute of Chartered Secretaries and Administrators, United Kingdom. He received his master of economics from Chuo University, Tokyo, Japan, majoring in development economics, and the doctor of philosophy in economics from Keio University, Tokyo, Japan, majoring in development and environmental economics. His research interests primarily focus on various aspects of sustainable development studies, environmental conservation and environmental ethics. 